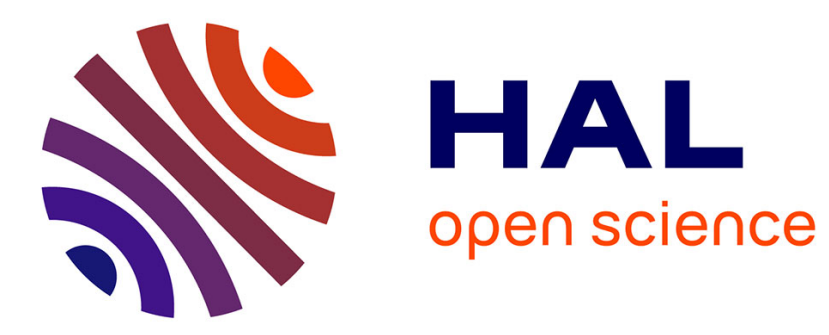

\title{
Soil arthropods in a developmental succession on the Nouragues inselberg (French Guiana)
}

Charlotte Kounda-Kiki, Anne Vaçulik, Jean-François Ponge, Corinne Sarthou

\section{To cite this version:}

Charlotte Kounda-Kiki, Anne Vaçulik, Jean-François Ponge, Corinne Sarthou. Soil arthropods in a developmental succession on the Nouragues inselberg (French Guiana). Biology and Fertility of Soils, 2004, 40 (2), pp.119-127. 10.1007/s00374-004-0749-z . hal-00497168

\section{HAL Id: hal-00497168 \\ https://hal.science/hal-00497168}

Submitted on 2 Jul 2010

HAL is a multi-disciplinary open access archive for the deposit and dissemination of scientific research documents, whether they are published or not. The documents may come from teaching and research institutions in France or abroad, or from public or private research centers.
L'archive ouverte pluridisciplinaire HAL, est destinée au dépôt et à la diffusion de documents scientifiques de niveau recherche, publiés ou non, émanant des établissements d'enseignement et de recherche français ou étrangers, des laboratoires publics ou privés. 


\title{
Soil arthropods in a developmental succession on the Nouragues inselberg
}

\section{(French Guiana)}

\author{
C. Kounda-Kiki, A. Vaçulik, J. F. Ponge and C. Sarthou
}

Muséum National d'Histoire Naturelle, CNRS UMR 5176, 4 Avenue du Petit-Chateau, 91800

Brunoy, France

Correspondence: C. Kounda-Kiki. E-mail : c.kounda-kiki@laposte.net

\begin{abstract}
Tropical inselbergs are isolated rock outcrops with a special type of vegetation surrounded by rain forest. They are exposed to harsh climate (alternation of heavy rain and severe drought) and provide few nutrients for plant growth. The aim of our study was to investigate a possible correlation between primary plant succession, size and diversity of soil arthropods. The study site was the Nouragues inselberg, in French Guiana (South America). Nine soil samples (three samples in each vegetation type) were taken for study of soil arthropod communities and their food habits in three habitat types: Pitcairnia geyskesii (Bromeliaceae), Clusia minor (Clusiaceae) and Myrcia saxatilis (Myrtaceae) represent three stages in a primary plant succession on this inselberg. Soil arthropods were classified into morphospecies under the dissecting microscope and their food habits were characterized by examining their gut contents under the light microscope. A variation in food habits was observed, cyanobacteria being found in arthropod guts only during Pitcairnia stage, being replaced by plant material at Myrcia stage. Carnivory was prominent in oribatid mites, contrary to temperate records. All our samples contained large numbers of microarthropods, principally mites and collembolans. At Myrcia stage arthropod density was significantly higher than at the two other stages. Macro-invertebrates are present only at late and intermediate successional stages. The number
\end{abstract}


of macro-predators increased by a factor of 10 in species richness and 100 in abundance along the succession. These results suggest that abundance and diversity of soil arthropod increased throughout plant succession and show the importance of organic matter as an explanation for the observed phenomenon.

Key words: Inselberg-Primary plant succession-Morphospecies-Food habits-Microarthropods

\section{Introduction}

The term inselberg (island hill in German), was proposed by Bornhart (1900) to characterize isolated rock outcrops which rise abruptly from the surrounding landscape. They occur in many regions of the tropics and subtropics, as well as in temperate biomes. Inselbergs exhibit very particular soil and microclimate conditions, which only few organisms can tolerate. French Guiana inselbergs consist of Precambrian granites (Choubert 1974; Hurault 1963, 1967) and they support a discontinuous, xeric and low vegetation, commonly called rock savanna, which is well adapted to granite exposed directly to the sun. Cyanobacterial films cover nearly all surfaces not occupied by rock savanna. These prokaryotic organisms fix atmospheric nitrogen, and they are the first colonizers of the granite, accelerating mineral weathering and liberating nutrients for the initiation of primary plant succession (Sarthou et al. 1995).

Studies of plant communities have indicated a gradual increase in species richness during early stages of primary succession (Drury and Nisbet 1973; Myster and Pickett 1992) while this process is reversed at late, forested stages (Christensen 1977; Howard and Lee 2003). The few studies which have been carried out on arthropods in successions indicate a 
parallel increase (Brown and Southwood 1983; Steffan-Dewenter and Tscharntke 1997) or decrease (Southwood et al. 1979; Paquin and Coderre 1997) in species richness.

There have been many studies of the vegetation of the Nouragues inselberg, located in French Guiana (South America). Sarthou (1992) described three stages of the plant succession on well-drained medium slopes, which were identified by their homogeneous physiognomy and structure: a herbaceous community dominated by the bromeliad Pitcairnia geyskesii and two shrub communities dominated by Clusiaceae (Clusia minor) and Myrtaceae (Myrcia saxatilis), respectively. They form, in this order, the three main stages of the development of the rock savanna ecosystem.

However, until recently there have been no studies of the soil fauna and their microenvironment (Vaçulik et al. 2004). In particular we want to test the hypothesis of an increase in animal size and diversity of functional groups during the development of ecosystems which had been postulated by Odum (1969) on theoretical bases and applied to soil fauna (Rusek 1978; Goralczyk 1998; Goralczyk et al. 1999; Verhoeven 2002). To test this hypothesis, we studied the distribution of soil arthropods and their food habits at each successional stage.

\section{Materials and methods}

\section{Study area}

The field work was carried out at the Nouragues inselberg ( $411 \mathrm{~m}$ above sea level), which is located in the Nouragues natural reservation $\left(4^{\circ} 5^{\prime} \mathrm{N}\right.$ and $\left.52^{\circ} 42^{\prime} \mathrm{W}\right)$. The inselberg is composed of a tabular outcrop of Caribbean granite, of pinkish monzonitic-type, containing 
$27 \%$ potassium-feldspar (orthoclase) and $37 \%$ plagioclase, along with $33 \%$ quartz as coarsegrained crystals and 2\% accessory minerals (pyroxene, corundum, apatite) (Grimaldi and Riéra 2001). The whole-rock chemical composition (Sarthou 1992) shows that the granite is highly siliceous $\left(76.4 \% \mathrm{SiO}_{2}\right)$ and rich in alkalis $\left(4.6 \% \mathrm{~K}_{2} \mathrm{O}, 4.2 \% \mathrm{Na}_{2} \mathrm{O}\right)$. The climate is tropical humid, and is characterized by a dry season (from July to November) and a wet season (from December to June) interrupted by a very short dry season in March. Mean annual precipitation is $3000-3250 \mathrm{~mm}$. The daily temperature ranges between $18-55^{\circ} \mathrm{C}$ and the daily air humidity between $20-100 \%$ (Sarthou 1992). The temperature of the bare rock surface may reach $75^{\circ} \mathrm{C}$ in the dry season. Most of the surface of the granitic outcrop is covered by cyanobacteria (Sarthou et al. 1995). The bromeliad Pitcairnia geyskesii, the prevailing plant of the inselberg, is an epilithic species $(30-50 \mathrm{~cm}$ tall) which always forms dense carpets of varying size (decimeters to decameters in diameter), covering low to medium slopes as well as gullies and shallow depressions. The Clusia minor community is also widespread. It represents the shrub vegetation unit of the rock savanna, forming dense thickets, 2-8 $\mathrm{m}$ tall. This community occurs both in depressions and slopes, on sandy and organic soils, respectively. Myrtaceae (Myrcia saxatilis) occur as both shrubs and trees. There was no obvious sign of human activity on the study area.

\section{Soil sampling procedure}

Samples were collected in April 2002 during a rainy period at each successional stage by forcing an aluminum cylinder $15 \mathrm{~cm}$ diameter and $10 \mathrm{~cm}$ height into the topsoil until the granite was reached. In soil thicker than $10 \mathrm{~cm}$ only the top $10 \mathrm{~cm}$ were sampled. Three samples were taken in each vegetation type, but at different places within the inselberg, in order to ensure representativity. For Pitcairnia carpets, sampling was done in the organic 
matter accumulated under cyanobacterial crusts which border them upslope, given that soil and organic matter are absent at the inside of epilithic carpets, due to intense run-off.

For the Pitcairnia stage, Pit1 was taken in a very small (60 cm diameter), Pit2 in a medium (3-5 m) and Pit3 in a large (10-15 m) carpet of Pitcairnia geyskesii. For the Clusia stage, Clu1 was taken at the inside of a shrub thicket of Clusia minor surrounded by a ring of Pitcairnia geyskesii, Clu2 was taken in the downslope layering part of another shrub thicket, the upslope part of which was already colonized by Myrcia saxatilis, while Clu3 was taken in the upslope layering of another shrub thicket, not surrounded by Pitcairnia geyskesii. For the Myrcia stage, Myr1 was taken at the centre of an old tree thicket of Myrcia saxatilis, surrounded by a ring of Clusia minor with dead and starving remnants of Pitcairnia geyskesii, while Myr2 and Myr3 were taken at the inside of two younger thickets of Myrcia saxatilis, surrounded by Clusia minor. Dead stems of Clusia. minor were observed on the ground in Myr3.

Fauna extraction and analysis

Soil fauna samples were sealed in plastic bags and transported to the laboratory (Brunoy, France) within two days for extracting arthropods using Berlese-Tullgren funnels (Edwards and Fletcher 1971). Animals were preserved into 95\% ethanol. Care was taken that ethanol vapour did not enter extraction funnels, by placing the collecting tubes far under the funnel mouth. Arthropods were separated into morphospecies, on the basis of characters observable under a dissecting microscope. Biodiversity indices were calculated using morphospecies following Oliver and Beattie (1996). 
The size of adults of all morphospecies (overall length of body, appendices excluded) was measured to the nearest $0.04 \mathrm{~mm}$, using an eye piece reticle. Morphospecies were grouped into three size classes: class $1(<0.4 \mathrm{~mm})$, class $2(0.4-1 \mathrm{~mm})$, and class $3(>1 \mathrm{~mm})$.

Soil invertebrates were mounted in chloral-lactophenol (25 ml lactic acid, $50 \mathrm{~g}$ chloral hydrate, $25 \mathrm{ml}$ phenol) for examination of their gut contents under phase contrast at $\mathrm{x} 400$ magnification (Ponge 1991). Gut contents were divided into nine categories: plant material, cyanobacteria, fungal material (spores and hyphae), humified organic matter, bacteria, mineral matter, pollen, animal matter and empty guts. The only visible structures were those which have not already been solubilized during digestion. Any dissolved or assimilated material could not be seen under the microscope.

Morphospecies were classified into four categories, according to the presence or absence of animal prey, plant and microbial material, and current knowledge on the taxa. Micropredators included gamasid and trombidid mites, and a few oribatid mites with animal prey in their gut. Macropredators included carnivorous macro-arachnids (spiders, pseudoscorpions), centipedes and carnivorous beetles. Microsaprophytophages included most oribatid mites, uropodid mites, Ellipura (springtails and Protura), and insect larvae (no one was found with prey in the intestine). Macrosaprophytophages included millipedes, woodlice, adult flies, non-carnivorous beetles and other insects.

\section{Data analysis}

Abundance of animals and numbers of morphospecies were used for the calculation of total population size of arthropods and species richness, respectively. To compare the species 
richness of samples on the same volume or abundance basis, we calculated the theoretical number of morphospecies per unit volume (one $\mathrm{cm}$ thick humus) and per 200 individuals by a jackknife method (Legendre and Legendre 1998). The jackknife was replicated ten times, allowing to compute an average value for each sample. We found that ten replicates were enough to give a confidence interval (standard error of the mean times Student's $t$ ) of less than $10 \%$ of the mean. This procedure allowed non-biased estimates of biodiversity when comparing samples of varying size, which was the case here, due to variable depth sampled.

Data were analyzed by correspondence analysis (Greenacre 1984). Active variables (animals groups, percentages of food items, arthropod densities, number of morphospecies, raw or estimated per $\mathrm{cm}$ or per 200 individuals, body size) as rows and samples as columns were simultaneously projected on the first factorial axis, i.e. that explaining best the global variation.

All variables were transformed into $X=(x-m) / s+20$, where $x$ is the original value, $m$ is the mean of a given variable, and $s$ is its standard deviation. The addition to each standardized variable of a constant factor of 20 allows all values to be positive, correspondence analysis dealing only with positive numbers. Following this transformation, factorial coordinates of variables can be interpreted directly in term of their contribution to the factorial axes: the farther a variable is projected from the origin of the axes (barycentre) along a given direction (along a factorial axis) the more it contributes to this axis. Variables were doubled in order to allow for the dual nature of most parameters (low values are as important as high values). To each variable $X$ was thus associated a twin $X^{\prime}$ varying in an opposite sense $\left(X^{\prime}=40-X\right)$. Such a doubling proved useful when dealing with ecological gradients (Ponge et al. 1997) or when it 
was judged interesting to classify samples according to their bulk abundance, besides changes in species composition (Loranger et al. 1998).

The Mann-Whitney non-parametric procedure was used to establish significant differences between pairs of successional stages, using 5\% as the significance level.

\section{Results}

The composition of soil fauna

The total number of arthropods counted was 5680. They were classified into 239 morphospecies which included 9 higher taxa: Acarida (mites), other Arachnida (spiders and pseudoscorpions), Myriapoda (millipedes and centipedes), Isopoda (woodlice), Ellipura (mostly Collembola but including also some Protura), Coleoptera (beetles), Diptera (flies), other Insecta, other Arthropoda (Table 1). Among arthropods, mites were the most diverse and abundant group, followed by springtails (Collembola).

Table 1 shows that the mean number of morphospecies per sample and the thickness of humus profiles increased (Mann-Whitney test, $\mathrm{P}<0.05$ ) from Pitcairnia to Clusia and Myrcia stages. When the number of morphospecies was weighted by the sampling volume, the only increase was from Clusia to Myrcia stages (x 1.6). The number of arthropods at the Clusia stage was half that observed at the Myrcia stage, Pitcairnia being intermediate. When weighted by thickness, Pitcairnia was by far the most populated environment, while the ratio Clusia:Myrcia (1:2) did not change. 
The size of soil arthropods was affected by the plant succession (Table 1). Although the mean size did not change, either calculated per morphospecies or per individual, the balance between the three size classes varied to a great extent. More small arthropods $(<0.4$ $\mathrm{mm}$ ) and fewer big arthropods (>1 mm) were found in Pitcairnia, when compared with the two later stages. Both total abundance and diversity of Myriapoda and Arachnida other than Acarida (mostly spiders and pseudoscorpions) increased dramatically from Pitcairnia to Clusia and Myrcia. The species richness of mites (Acarida) and springtails (Ellipura) increased similarly, but this was not reflected in their population size (Table 1). The density of Ellipura was halved in Clusia compared with the two other stages, while the number of morphospecies was as higher in Clusia than in Myrcia and three-fold that in Pitcairnia. An increase in the abundance of beetles (Coleoptera) and termites and ants (other Insecta) was observed from Clusia to Myrcia.

\section{Turnover of species}

Morphospecies were classified according to their occurrence in one or several steps of the plant succession. The distribution of these classes according to the total number of morphospecies and of individuals is shown in Figure 1. A group of 20 species is common to the three stages studied, thus it is the basic arthropod community of the inselberg. It represents more than a third of the total richness at the pioneering Pitcairnia stage. However, it comprised a lesser part of the richness at the two other stages. These common species include mites (for more than half), springtails and insects (termites included).

Many more species were common to Clusia and Myrcia stages than to Pitcairnia and one or the other stages (Fig. 1). This holds both for morphospecies and individuals. This 
indicates that the transition from herbaceous to woody stages is accompanied by a high turnover of arthropod species. Fewer changes occurred during the transition from Clusia to Myrcia stages, despite the presence of species typical of each stage. These specialized species are numerous (almost half the total richness) but their population size is small (no more than one fifth of the total arthropod abundance).

\section{Diets}

Percentages of the food categories found in intestines varied across successional stages (Table 1). Overall microbial material (mostly fungal hyphae and bacteria) was heavily consumed, followed by plant material, humus, animal prey and at lowest frequency mineral matter (Table 1). The presence of animal prey in five oribatid mite morphospecies was unexpected, as was the absence of animal prey in all but one beetle morphospecies. Cyanobacteria, although abundant at the Pitcairnia stage, were consumed only by adult insects. Oribatid mites did not consume them, although they ingested higher plant and fungal material. Pollen and mineral matter were more frequently encountered at the Myrcia stage. More species consuming fungal hyphae were found at the Clusia stage than other stages.

There was a dramatic increase in the contribution of macropredators to the arthropod community, both in species and individuals, across the succession. The increase was by 10 in species richness, and by 100 in population size (Table 1). Conversely, the contribution of macrosaprophytophages decreased in richness, from a third to a quarter of the total number of species, but this decrease was not reflected in the population size. Thus the increase in biodiversity we observed along the successional trend (mostly from Pitcairnia to Clusia stages) was mainly due to macropredators. 
Synthesis of results by correspondence analysis

Correspondence analysis, made on all population and gut content variables describing the arthropod community, revealed differences among stages along the successional gradient. Coordinates along Axis 1 discriminated the three vegetation stages (Table 1). Only the first axis of correspondence analysis, explaining $34 \%$ of the total variance, was interpreted, and the graphical presentation of the data (samples and variables) is given in Figures 2, 3, and 4. The projection of the nine samples reflected their position throughout the plant succession. A clear distinction can be made between Pitcairnia and the two other vegetation types. The Pitcairnia stage, on the negative side of Axis 1, is characterized by low thickness of organic matter, low diversity of morphospecies and dominance of small-sized organisms (Fig. 2). Among the three samples taken along Pitcairnia carpets, Pit 3 had higher Axis 1 coordinates, indicating a higher developmental stage of the arthropod community. At the opposite side of Axis 1, Myrcia samples, and among them more particularly Myr 1, were characterized by a high thickness of organic matter, a higher diversity of arthropod species and the dominance of bigger forms. Clusia samples were projected on the positive side of Axis 1, but near the origin, thus indicating that the abovementioned features were not so much pronounced at this stage of the plant succession. The examination of the scaling of samples along Axis 1 revealed that Clusia and Myrcia samples differed less from each other than they differed from Pitcairnia samples. The total number of arthropods was roughly centered around the origin, thus indicating that it did not contribute to Axis1 to a great extent.

The projection of group taxa (Fig. 3) showed that all arthropod groups but Diptera (flies) exhibited a higher diversity (comprised a higher number of morphospecies) at late 
stages of the plant succession (positive side of Axis 1). This global trend was not reflected in the abundance of individuals (population size) per animal group.

The successional gradient depicted by Axis 1 concerned also alimentary categories which were well spread over this axis (Fig. 4). The Pitcairnia stage was associated with the abundance of cyanobacteria and fungal spores, while the Myrcia stage, and to a lesser extent the Clusia stage, was characterized by pollen grains, mineral matter and humus. Bacteria, when scored on the basis of individuals, characterized the Myrcia stage, while they did not characterize any stage when scored on the basis of morphospecies, which indicated that they were found in some species with a high population size under Myrcia. Fungal spores and fungal hyphae were not projected together, the second food category being near the origin on the positive side of Axis 1. This could indicate a decrease in the sporulation rate of soil fungi along the successional gradient. Empty guts were more often found at the Pitcairnia stage when scored on individuals. As above, this indicated that some abundant arthropod species with a fluid regime were found at this early stage, or that most individuals were in a resting stage.

\section{Discussion}

The cyanobacterial crusts associated with the pioneering Pitcairnia carpets had high arthropod populations but low diversity compared with woody stages of the plant succession (Clusia, Myrcia). At the intermediate Clusia stage, there were fewer individuals, but higher diversity when species richness was weighted by the population size. The last stage, Myrcia, was characterized by both high individual and species richness according to the importance of organic matter. This last observation is in accordance with results found by Goralczyk et al. 
(1999) and by Verhoeven (2002), where soil animals become more diverse with soil development.

The size of arthropods is lower in Pitcairnia than in the two other vegetation types, as this has been observed with plants along successional gradients. The size of species should vary according to the stability of habitats (Peters 1983; Ebenman and Person 1988). More macroarthropods, especially macropredators, were present at the two later stages, which were similar except for the abovementioned decrease in total arthropod abundance under Clusia. It might be argued that the absence of macropredators and the fixation of atmospheric nitrogen into organic matter may contribute to favour animal life in cyanobacterial crusts, in spite of restricted space. At the Myrcia stage, the development of a thick humus cover $(30 \mathrm{~cm}$ to $1 \mathrm{~m}$, Sarthou and Grimaldi 1992) may result in an increase in deep refuges for microarthropods, thus preventing predation from decreasing their population size.

Feeding habits were shown to vary along the successional gradient. Pollen, mineral and humified matter characterized late successional stages. This accompanied the development of vegetation (higher plants) and the associated building of thicker organic soil profiles. Although soils on tropical inselbergs are superficial and mostly organic (Sarthou and Grimaldi 1992), we observed the presence of earthworm casts in the organic matter accumulated under Myrcia, and the anchorage of the root system of trees at this stage, contrary to earlier developmental stages. This may account for the presence of mineral grains at the top of humus profiles. Cyanobacteria, which are the main component of humus profiles at the Pitcairnia stage (Vaçulik et al. 2004), were not heavily consumed by most arthropods. However, their presence in some animal guts at both Pitcairnia and Clusia stages indicated that, despite the weak occurrence of these autotrophic organisms under the shade of Clusia, 
they constituted a relic component of the ecosystem, inherited from earlier, better illuminated stages. Cyanobacteria were almost absent under Myrcia, at least according to our census of arthropod guts.

Leaf litter was present at Clusia and Myrcia stages, while there was practically no litter at the Pitcairnia stage, except a thin cyanobacterial crust (Vaçulik et al. 2004). Thus the development of vegetation was accompanied by an increase in organic matter production, enabling more organisms to live in the ecosystem, according to the scheme suggested by Odum (1969), and as applied to soil development by Rusek (1978). The observed increase in arthropod diversity per unit surface, which affected all taxa, may be explained by the increase in food availability and habitat size. Within this global trend, the particular increase in large arthropods can be explained by more pore space and refuges under thick litter (Garay and Hafidi 1990). Hooper et al. (2000) demonstrated that the diversity of soil fauna increased together with aboveground production which is prone to occur along our successional gradient from prostrated (Pitcairnia) then to shrub (Clusia) and to thicket (Myrcia) vegetation.

In addition to these observations, other details revealed interesting patterns in soil animal communities of tropical inselbergs. Mite guts exhibited more fungal than plant material. Other researchers found similar results in temperate soils (Daniel and Engelmann 1961; Luxton 1979). However, we observed several oribatid mite species which presented an omnivore diet, including animal prey, as has been found in temperate peat moss bogs (BehanPelletier and Hill 1983). This might be explained by a partial predatory behaviour in an environment poor in nitrogen. The high percentage of empty guts at the Pitcairnia stage should be also noted. There are several possible explanations for this phenomenon. It could be 
due to nutritional shortage but also to the physiological stage of the animals (Joosse and Testerink 1977) or to sucking feeding habits.

We have shown that different successional stages have different characteristics with respect to density of soil arthropods, total number of species present, and mean number of species per sample, and that this could be explained by vegetation dynamics and accompanying changes in food and space availability. Another hypothesis, based upon Connell and Slatyer (1977) "facilitation"model, is that soil arthropods themselves may alter the environment so as to cause changes in the composition of plant communities. Both hypotheses are not mutually exclusive, as has been demonstrated in temperate forest soils (Bernier and Ponge 1994).

\section{Acknowledgements}

We wish to thank the Centre National de la Recherche Scientifique for financial support and commodities, in particular P. Charles-Dominique and his staff at the Nouragues Field Station.

\section{References}

Behan-Pelletier VM, Hill SB (1983) Feeding habits of sixteen species of Oribatei (Acari) from an acid peat bog, Glenamoy, Ireland. Rev Ecol Biol Sol 20: 221-267

Bernier N, Ponge JF (1994) Humus form dynamics during the sylvogenetic cycle in a mountain spruce forest. Soil Biol Biochem 26: 183-220

Bornhart W (1900) Zur Oberflächengestaltung und Geologie Deutsch-Ostafrikas. Berlin 
Brown VK, Southwood TRE (1983) Trophic diversity, niche breadth, and generation times of exopterygote insects in a secondary succession. Oecologia 56: 220-225

Choubert B (1974) Les Précambriens des Guyanes. Mém Bur Rech Géol Min 81: 1-212

Christensen NL (1977) Changes in structure, pattern, and diversity associated with climat forest maturation in piedmont, North Carolina. Am Midl Nat 97: 176-188

Connell JH, Slatyer RO (1977) Mechanism of succession in natural communities and their role in community stability and organisation. Am Nat 111: 1119-1144

Daniel R P, Engelmann M D (1961) Fungi as source of food for soil mites. Am J Bot 48: 538

Drury WH, Nisbet ICT (1973) Succession. J Arnold Arbor 54: 331-368

Ebenman B, Person L (1988) Size-structured populations. Springer, Berlin.

Edwards CA, Fletcher KE (1971) A comparison of extraction methods for terrestrial arthropods. In: Phillipson $\mathbf{J}$ (ed) Methods of study in quantitative soil ecology: population, production and energy flow. Blackwell, Oxford, pp 150-185

Garay I, Hafidi N (1990) Study of a mixed forest litter of hornbean (Carpinus betulus L.) and oak (Quercus sessiliflora Smith). III. Organization of the edaphic macro-arthropod community as a function of litter quantity. Acta Oecol 11: 43-60

Goralczyk K (1998) Nematodes in a coastal dune succession: Indicators of soil properties?. Applied Soil Ecology 9: 465-469

Goralczyk K, Verhoeven R (1999) Bodengenese als Standortfaktor für Mikrofauna- Ciliaten und Nematoden in Dünenböden, In: Koehler H, Mathes K, Breckling B (eds), Bodenökologie interdisziplinär, Springer, Berlin, pp 105-118

Greenacre MJ (1984) Theory and applications of correspondence analysis. Academic Press, London 
Grimaldi M, Riéra B (2001) Geography and climate. In: Bongers F, Charles-Dominique P, Forget PM, Théry M (eds) Nouragues: dynamics and plant-animal interactions in a neotropical rainforest. Kluwer, Dordrecht, pp 9-18

Hooper DU, Bignell DE, Brown VK, Brussaard L, Dangerfield JM, Wall DH, Wardle DA, Coleman DC, Giller KE, Lavelle P, Van Der Putten WH, De Ruiter PC, Rusek J, Silver WL, Tiedje JM, Wolters V (2000) Interactions between aboveground and belowground biodiversity in terrestrial ecosystems: patterns, mechanisms, and feedbacks. BioScience 50: 1049-1061

Howard LF, Lee TD (2003) Temporal patterns of vascular plant diversity in southeastern New Hampshire forests. For Ecol Manag 185: 5-20

Hurault J (1963) Recherches sur les inselbergs granitiques nus en Guyane française. Rev Géomorphol Dyn 4: 49-61

Hurault J (1967) L'érosion régressive dans les régions tropicales humides et la genèse des inselbergs granitiques. IGN, Paris

Joosse ENG, Testerink (1977) The role of food in the population dynamics of Orchesella cincta (Linné) (Collembola). Oecologia 29: 189-204

Legendre P, Legendre L (1998) Numerical ecology, $2^{\text {nd }}$ English ed. Elsevier, Amsterdam

Loranger G, Ponge JF, Blanchart E, Lavelle P (1998) Impact of earthworms on the diversity of microarthropods in a vertisol (Martinique). Biol Fertil Soils 27: 21-26

Luxton M (1979) Food and energy processing by oribatid mites. Rev Ecol Biol Sol 16: 103111

Myster RW, Pickett STA (1992) Dynamics of associations between plants in ten old fields during 31 years of succession. J Ecol 80: 291-303

Odum (1969) The Strategy of ecosystem development. Science 164: 262-270 
Oliver I, Beattie AJ (1996) Designing a cost-effective invertebrate survey: a test of methods for rapid assessment of biodiversity. Ecol Appl 6: 594-607

Paquin P, Coderre D (1997) Comparison of macro-arthropod communities associated with three succession stages of the Canadian boreal forest. Oecologia 112: 104-111

Peters RH (1983) The ecological implications of body size. Cambridge University Press

Ponge JF (1991) Food resources and diets of soil animals in a small area of Scots pine litter. Geoderma 49: 33-62

Ponge JF, Arpin P, Sondag F, Delecour F (1997) Soil fauna and site assessment in beech stands of the Belgian Ardennes. Can J For Res 27: 2053-2064

Rusek J (1978) Pedozootische Sukzessionen während der Entwicklung von Ökosystemen. Pedobiologia 18: 426-433

Sarthou C (1992) Dynamique de la végétation pionnière sur un inselberg en Guyane Française. Doctorate thesis, Paris

Sarthou C, Grimaldi C (1992) Mécanismes de colonisation par la végétation d'un inselberg granitique en Guyane Française. Rev Ecol (terre vie) 47 : 329-349

Sarthou C, Thérézien Y, Couté A (1995) Cyanophycées de l'inselberg des Nouragues (Guyane Française). Nova Hedwigia 61: 85-109

Southwood TRE, Brown VK, Reader PM (1979) The relationships of plant and insect diversities in succession. Biol J Linnean Soc 12: 327-348

Steffan-Dewenter I, Tscharntke T (1997) Early succession of butterfly and plant communities on set-aside fields. Oecologia 109: 294-302

Vaçulik A, Kounda-Kiki C, Sarthou C, Ponge JF (2004) Soil invertebrate activity in biological crust on tropical inselbergs. Eur J Soil Sci 55 (in press)

Verhoeven R (2002) Ciliates in coastal dune soils of different stages of development. Eur J Soil Biol 38: 187-191 


\section{Figure legends}

Figure 1 Distribution of morphospecies according to their occurrence in one or several stages of the plant succession (three $1.8 \mathrm{dm}^{3}$ samples each). (a) Mean number of morphospecies per sample. (b) Mean number of individuals per $\mathrm{m}^{2}$ Pit $=$ Pitcairnia, $\mathrm{Clu}=$ Clusia, $\mathrm{Myr}=$ Myrcia .

Figure 2 Correspondence analysis. Projection of samples and a selection of active variables on the first factorial axis. Active variables were arbitrarily disposed on one side and samples on the other side. When active variables were doubled (see text) higher values (original values) were indicated in bold type while lower values (conjugate values) are in italic type. Position of the origin of the axis (barycentre) is indicated by an arrow. Positive and negative coordinates are on lower and upper side, respectively. For the sake of clarity sample codes and variable names have been displaced horizontally, their projection on Axis 1 being indicated only by their vertical position.

Figure 3 Correspondence analysis. Projection of samples and other active variables (higher taxa) on the first factorial axis. Other details as for Fig. 2.

Figure 4 Correspondence analysis. Projection of samples and other active variables (gut content categories) on the first factorial axis. Other details as for Fig 2. 
Table 1 Mean values (with standard error) of the mains variables featuring soil arthropod communities in the three studied successional stages (3 replicates each). Results of

calculations based both on morphospecies diversity and abundance. Significant differences between pairs of successional stages (Mann-Withney $U$ test) are indicated by different letters, combining results from three tests

\begin{tabular}{llll}
\hline & Pitcairnia & Clusia & Myrcia \\
\hline Thickness of litter/humus sampled $(\mathrm{cm})$ & $3 \pm 0.6_{\mathrm{b}}$ & $9.3 \pm 0.7_{\mathrm{a}}$ & $10 \pm 0_{\mathrm{a}}$ \\
& & & \\
Number of morphospecies per sample & $28.7 \pm 8.2_{\mathrm{b}}$ & $67.7 \pm 4.1_{\mathrm{a}}$ & $89 \pm 12.9_{\mathrm{a}}$ \\
Number of morphospecies per cm & $22.3 \pm 6.4_{\mathrm{b}}$ & $22 \pm 1.7_{\mathrm{b}}$ & $35.7 \pm 6.6_{\mathrm{a}}$ \\
Number of morphospecies per 200 individuals & $21 \pm 4_{\mathrm{b}}$ & $53.1 \pm 1.3_{\mathrm{a}}$ & $56.6 \pm 6.2_{\mathrm{a}}$
\end{tabular}

Number of arthropods per $m^{2} \quad 42232 \pm 23235_{a b} \quad 20955 \pm 3039_{b} \quad 43952 \pm 10661_{a}$ Number of arthropods per $\mathrm{m}^{2} /$ humus depth $\left(\mathrm{cm} 12885 \pm 4940_{\mathrm{a}} \quad 2224 \pm 181_{\mathrm{b}} \quad 4414 \pm 1064_{\mathrm{a}}\right.$

\begin{tabular}{|c|c|c|c|}
\hline Various diversity measures & & & \\
\hline Mean size of adults $(\mathrm{mm})$ & $1 \pm 0.1$ & $1.1 \pm 0.1$ & $1.1 \pm 0.04$ \\
\hline$\%$ class $1(<0.4 \mathrm{~mm})$ & $40.4 \pm 5$ & $38.4 \pm 1.2$ & $34.2 \pm 2.3$ \\
\hline$\%$ class $2(0.4-1 \mathrm{~mm})$ & $34.7 \pm 8.9$ & $37.7 \pm 2.5$ & $39 \pm 3$ \\
\hline$\%$ class $3(>1 \mathrm{~mm})$ & $24.2 \pm 5.5$ & $24.8 \pm 3$ & $26.4 \pm 2$ \\
\hline Total Acarida & $14.3 \pm 3.5 \mathrm{~b}$ & $33.3 \pm 2.7 \mathrm{a}$ & $46.3 \pm 9.3_{a}$ \\
\hline Total other Arachnida & $0.3 \pm 0.3_{b}$ & $5.3 \pm 2_{a}$ & $6.7 \pm 1.3_{a}$ \\
\hline Total Myriapoda & $\mathrm{ob}_{\mathrm{b}}$ & $3.3 \pm 0.3_{a}$ & $4 \pm 1_{\mathrm{a}}$ \\
\hline Total Isopoda & 0 & 0 & $0.7 \pm 0.7$ \\
\hline Total other Arthropoda & 0 & $0.3 \pm 0.3$ & $1 \pm 1$ \\
\hline Total Ellipura & $4 \pm 1.1_{b}$ & $13 \pm 0.6_{a}$ & $15.7 \pm 2.7 \mathrm{a}$ \\
\hline Total Coleoptera & $2.7 \pm 2.2$ & $4 \pm 1.5$ & $6.3 \pm 0.9$ \\
\hline Total Diptera & $3.7 \pm 0.3$ & $3.3 \pm 0.3$ & $2.3 \pm 0.7$ \\
\hline Total other Insecta & $3.7 \pm 1.2$ & $5 \pm 1.1$ & $6 \pm 2$ \\
\hline$\%$ micropredators & $30 \pm 4.1$ & $32 \pm 2$ & $31 \pm 3$ \\
\hline$\%$ macropredators & $0.7 \pm 0.7_{\mathrm{b}}$ & $8.6 \pm 2.9_{a}$ & $9.2 \pm 0.8_{a}$ \\
\hline$\%$ microsaprophytophages & $35.6 \pm 2.2$ & $38 \pm 2.2$ & $40.3 \pm 4.3$ \\
\hline$\%$ macrosaprophytophages & $33.8 \pm 2.7 \mathrm{a}$ & $22.2 \pm 3.7 \mathrm{~b}$ & $20 \pm 3.8_{b}$ \\
\hline$\%$ plant material & $13.5 \pm 0.2$ & $14.6 \pm 2.6$ & $12.1 \pm 1.2$ \\
\hline$\%$ cyanobacteria & $0.3 \pm 0.1_{\mathrm{a}}$ & $0.2 \pm 0.1 \mathrm{a}$ & $0.02 \pm 0.02_{b}$ \\
\hline \% fungal material (spores) & $1.7 \pm 1$ & $0.3 \pm 0.1$ & $0.6 \pm 0.2$ \\
\hline \% fungal material (hyphae) & $11.3 \pm 1_{b}$ & $15.5 \pm 0.7 \mathrm{a}$ & $15.5 \pm 2.4_{\mathrm{ab}}$ \\
\hline$\%$ humified organic matter & $7.2 \pm 1.1$ & $9 \pm 0.6$ & $8.4 \pm 0.4$ \\
\hline$\%$ bacteria & $5.2 \pm 1.1$ & $6.4 \pm 0.5$ & $4.4 \pm 0.5$ \\
\hline$\%$ mineral matter & $0.08 \pm 0.01_{b}$ & $0.2 \pm 0.03_{a}$ & $0.2 \pm 0.04 a$ \\
\hline$\%$ pollen & $\mathrm{O}_{\mathrm{b}}$ & $0.03 \pm 0.03_{\mathrm{ab}}$ & $0.06 \pm 0.01_{\mathrm{a}}$ \\
\hline$\%$ animal matter & $1.4 \pm 0.8$ & $2 \pm 0.7$ & $2.2 \pm 0.6$ \\
\hline$\%$ empty guts & $59.2 \pm 2.3_{a}$ & $51.8 \pm 1.4 b$ & $56.3 \pm 2.7_{\mathrm{ab}}$ \\
\hline Various abundance measures & & & \\
\hline Mean size of adults $(\mathrm{mm})$ & $0.7 \pm 0.1$ & $0.8 \pm 0.06$ & $0.79 \pm 0.04$ \\
\hline$\%$ class $1(<0.4 \mathrm{~mm})$ & $65.2 \pm 3.4 a$ & $49.6 \pm 7.7_{b}$ & $44.1 \pm 3.1_{b}$ \\
\hline$\%$ class $2(0.4-1 \mathrm{~mm})$ & $29.6 \pm 3.9$ & $38.5 \pm 6.5$ & $39.3 \pm 3.3$ \\
\hline$\%$ class $3(>1 \mathrm{~mm})$ & $5.2_{\mathrm{b}}$ & $11.9 \pm 1.2 \mathrm{a}$ & $16.6 \pm 2.7 \mathrm{a}$ \\
\hline Total Acarida & $473.7 \pm 306.7$ & $284.3 \pm 49$ & $516.7 \pm 165$ \\
\hline Total other Arachnida & $0.7 \pm 0.7_{\mathrm{b}}$ & $21 \pm 7.5 \mathrm{a}$ & $22.3 \pm 9.6 \mathrm{a}$ \\
\hline Total Myriapoda & $\mathrm{O}_{\mathrm{b}}$ & $10 \pm 5.1_{a}$ & $23 \pm 9_{a}$ \\
\hline Total Isopoda & 0 & 0 & $10 \pm 10$ \\
\hline Total other Arthropoda & 0 & $1.7 \pm 1.7$ & $2 \pm 2$ \\
\hline Total Ellipura & $158 \pm 13.5_{a}$ & $75.3 \pm 2.6_{b}$ & $173 \pm 25_{a}$ \\
\hline Total Coleoptera & $25.7 \pm 25.2_{\mathrm{ab}}$ & $4.7 \pm 1.9_{b}$ & $38.3 \pm 11.4 \mathrm{a}$ \\
\hline Total Diptera & $16.7 \pm 8.6$ & $5.7 \pm 0.7$ & $3.7 \pm 1.8$ \\
\hline Total other Insecta & $90 \pm 83.5_{\mathrm{ab}}$ & $14 \pm 5.5_{b}$ & $59.7 \pm 19.2_{a}$ \\
\hline$\%$ micropredators & $32.4 \pm 10$ & $18.6 \pm 4.1$ & $16.3 \pm 4.8$ \\
\hline$\%$ macropredators & $0.04 \pm 0.04_{b}$ & $5.6 \pm 1.5_{a}$ & $3 \pm 0.9 \mathrm{a}$ \\
\hline$\%$ microsaprophphytophages & $56.4 \pm 12.8$ & $66.4 \pm 3.1$ & $63.6 \pm 2.6$ \\
\hline$\%$ macrosaprophytophages & $11.2 \pm 6.3$ & $9.5 \pm 1.8$ & $17 \pm 4.5$ \\
\hline$\%$ plant material & $9.2 \pm 1.7$ & $15.9 \pm 4.8$ & $10.7 \pm 0.9$ \\
\hline$\%$ cyanobacteria & $0.1 \pm 0.05_{a b}$ & $0.05 \pm 0.01 \mathrm{a}$ & $0.002 \pm 0.002_{b}$ \\
\hline$\%$ fungal material (spores) & $1.6 \pm 1.4$ & $0.3 \pm 0.2$ & $0.4 \pm 0.2$ \\
\hline$\%$ fungal material (hyphae) & $15.7 \pm 3.4$ & $22.1 \pm 7$ & $22.7 \pm 1.9$ \\
\hline$\%$ humified organic matter & $5 \pm 3.7$ & $16.1 \pm 7$ & $15 \pm 1.7$ \\
\hline$\%$ bacteria & $2.7 \pm 1.4_{b}$ & $7.7 \pm 1.6_{\mathrm{ab}}$ & $7 \pm 0.4 a$ \\
\hline$\%$ mineral matter & $0.03 \pm 0.01_{b}$ & $0.1 \pm 0.01_{\mathrm{ab}}$ & $0.2 \pm 0.03_{a}$ \\
\hline$\%$ pollen & $\mathrm{ob}_{\mathrm{b}}$ & $0.008 \pm 0.008_{a}$ & $0.02 \pm 0.004 a$ \\
\hline$\%$ animal matter & $5.5 \pm 5.4 \mathrm{a}$ & $2 \pm 1.6 \mathrm{a}$ & $1.5 \pm 0.4_{b}$ \\
\hline$\%$ empty guts & $60.3 \pm 7.4 a$ & $35.6 \pm 1.1_{\mathrm{c}}$ & $42.5 \pm 0.5 b$ \\
\hline Axis 1 coordinates (correspondence analysis) & $-0.035 \pm 0.06_{c}$ & $0.008 \pm 0.003_{b}$ & $0.03 \pm 0.008_{a}$ \\
\hline
\end{tabular}



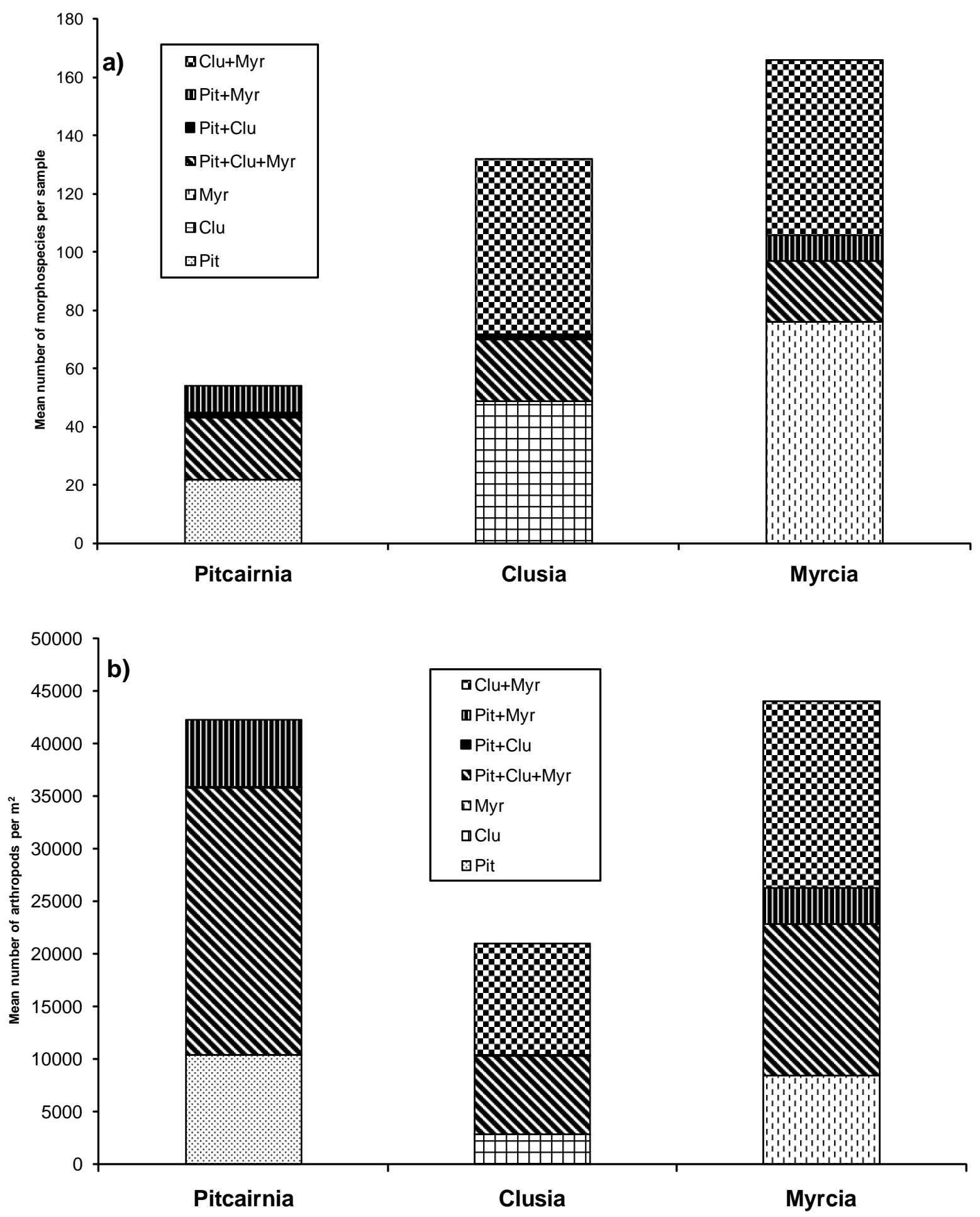

Fig. 1 


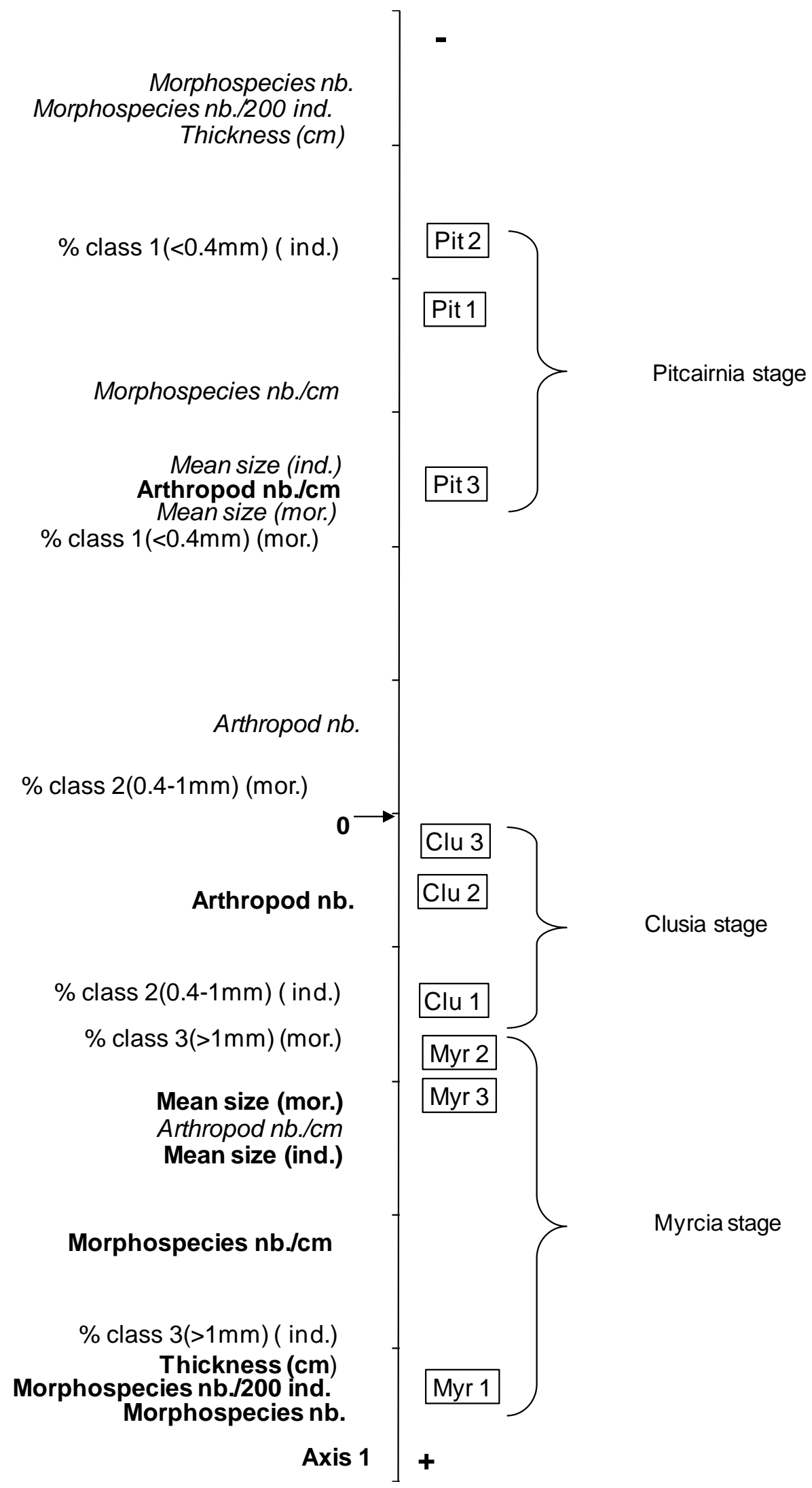

Fig. 2 
Total Myriapoda (mor.) Total Acarida (mor.) Total other Arachnida (mor.)

Total other Arachnida (ind.) Total Myriapoda (ind.)

Total Coleoptera (mor. Total other Insecta (mor.)

Total Isopoda (ind.) Total Isopoda (mor.)

Total Diptera (mor.) Total Diptera (ind.)

Total other Arthropoda (mor.)

Total other Arthropoda (ind.)

Total Acarida (ind.) Total Coleoptera (ind.)

Total Ellipura (ind.)

Total other Insecta (ind.)

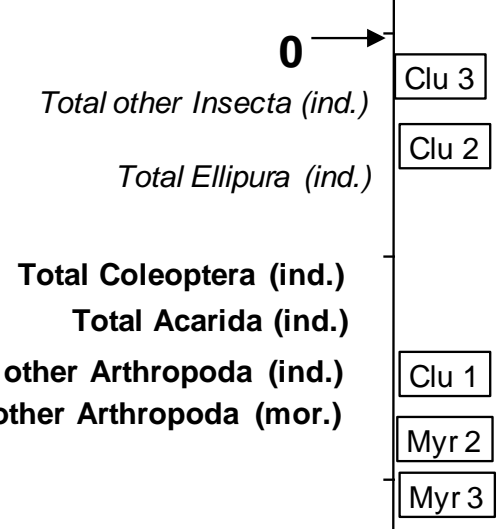

Total Diptera (ind.) Total Diptera (mor.)

Total Isopoda (ind.) Total Isopoda (mor.)

Total other Insecta (mor.)

Total Coleoptera (mor.)

Total Myriapoda (ind.)

Total other Arachnida (ind.)

Total Ellipura (mor.)

Total other Arachnida ( (mor.)

Total Myriapoda (mor.) Total Acarida (mor.)

Total other Arthropoda (ind.)

Fig. 3 


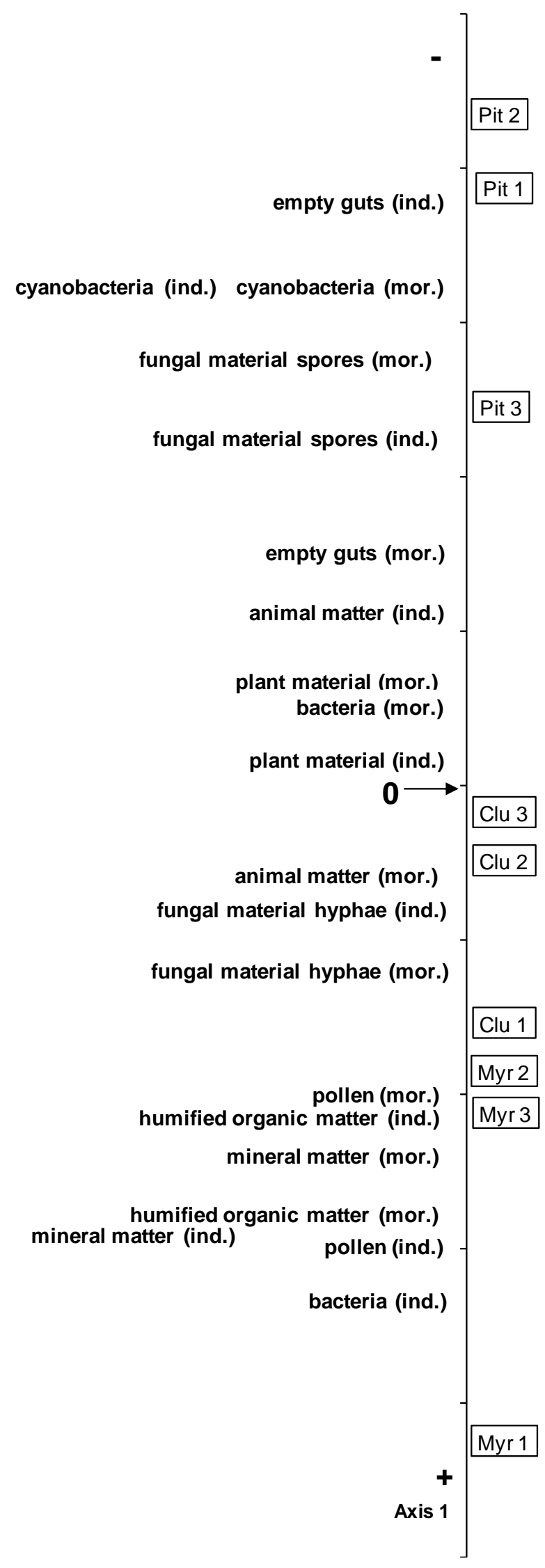

Fig. 4 